\title{
FAKTOR-FAKTOR YANG BERHUBUNGAN DENGAN PEMAHAMAN IBU HAMIL TENTANG SITIKER P4K DI WILAYAH KERJA UPT BLUD PUSKESMAS GUNUNGSARI TAHUN 2018
}

\author{
Marliana $^{1}$ dan Fachrudi Hanafi ${ }^{2}$ \\ ${ }^{1}$ Program Studi Diploma IV Kebidanan Politeknik Kesehatan Mataram \\ ${ }^{2}$ Program Studi Diploma III Kebidanan Politeknik Kesehatan Mataram
}

\begin{abstract}
Abstrak
Angka Kematian Ibu (AKI) di Indonesia mencapai 359 per 100.000 kelahiran hidup, tingginya angka kematian ibu ini disebabkan oleh berbagai penyebab yang kompleks, yaitu penyebab langsung dan tidak langsung. Penyebab langsung kematian ibu di Indonesia adalah perdarahan, infeksi, eklamsi, partus lama dan komplikasi abortus, serta penyebab tidak langsung yaitu sosial, budaya, ekonomi, tingkat pendidikan, fasilitas pelayanan kesehatan, dan gender.Salah satu upaya untuk menurunkan yaitu dengan Program Perencanaan Persalinan dan Pencegahan Komplikasi (P4K). Berdasarkan data yang didapatkan dari Dikes Lobar Tahun 2017 Puskesmas Gunung Sari memiliki ibu hamil terbanyak di Kabupaten Lombok Barat dengan jumlah 1.372 orang dan ibu hamil yang mengalami komplikasi maternal sebayak 237 orang. Dari $1.372 \mathrm{ibu}$ hamil masih terdapat ibu hamil yang mengalami komplikasi. Tujuan dari penelitian ini adalah untuk mengetahui Faktor-Faktor Apa Saja yang Berhubungan dengan Pemahaman Ibu Hamil Tentang Stiker P4K Di Wilayah Kerja Puskesmas Gunung Sari Tahun 2018. Metode penelitian ini menggunakan rancangan penelitian Observasi Analitik.Populasi dari penelitian ini adalah semua ibu hamil yang telah melakukan K1 dan belum melahirkan pada saat dilakukan penelitian di wilayah UPT BLUD Puskesmas Gunung Sari pada tahun 2018 di sebanyak 95 orang. Penelitian ini berlangsung menggunakan Simple Random Sampling, diperoleh 30 sampel dengan uji chi-square. Hasil uji statistik umur tidak memiliki hubungan dengan nilai ( $\mathrm{P}$ Value $=0,548)$, sedangkan pendidikan $(\mathrm{P}$ Value $=0,001)$, pekerjaan $(\mathrm{P}$ Value $=0,054)$, paritas $(\mathrm{P}$ Value $=0,004)$ artinya terdapat hubungan yang signifikan.Faktor pendidikan,pekerjaan, paritas berhubungan dengan pemahaman ibu hamil tentang stiker P4K. Sedangkan faktor umur tidak berhubungan dengan pemahaman ibu hamil tentang stiker $\mathrm{P} 4 \mathrm{~K}$.
\end{abstract}

Kata kunci : Pemahaman Ibu Hamil ; Stiker P4K

\section{FACTORS ASSOCIATED WITH PREGNANCY UNDERSTANDING ABOUT P4K STICKERS IN THE WORK AREA OF UPT BLUD GUNUNG SARI 2018}

\begin{abstract}
Maternal Mortality Rate (MMR) in Indonesia reaches 359 per 100,000 live births, the high maternal mortality rate is caused by various complex causes, namely direct and indirect causes. The direct causes of maternal death in Indonesia are bleeding, infection, eclampsia, prolonged labor and abortion complications, as well as indirect causes, namely social, cultural, economic, educational level, health care facilities, and gender. One effort to reduce the delivery plan and Complication Prevention (P4K). Based on data obtained from Lobar Dikes in 2017, Gunung Sari Public Health Center had the highest number of pregnant women in West Lombok Regency with 1,372 people and pregnant women who experienced maternal complications as much as 237
\end{abstract}


people. Of the 1,372 pregnant women there were still pregnant women who experienced complications. The purpose of this study is to find out what factors are related to the understanding of pregnant women about P4K stickers in the working area of Gunung Sari Public Health Center in 2018. This research used the research design of Analytical Observation. The population of this research is all pregnant women who have done $\mathrm{K} 1$ and not give birth at the time of research in UPT BLUD Puskesmas Gunung Sari in 2018 in as many as 95 people. This research was conducted using Simple Random Sampling, obtained 30 samples with chi-square test. Obtained age statistics test results have no relationship with value $(\mathrm{P}$ Value $=0.548)$, while education $(\mathrm{P}$ Value $=0.001)$, occupation $(\mathrm{P}$ Value $=0.054)$, parity $(\mathrm{P}$ Value $=0.004)$ means that there is a significant relationship. The factor of education,job,parity are relatedtion with pregnant women about $\mathrm{P} 4 \mathrm{~K}$ sticker, while the factor age is not relatedtion with pregnant women about $\mathrm{P} 4 \mathrm{~K}$ sticker.

Keywords: Understanding Pregnant Women ; P4K Stickers

\section{Pendahuluan}

Kesehatan ibu dan anak sebagi bagian dari tujuan SDGs dikarenakan masih tingginya angka kematian ibu serta angka kematian bayi yang merupakan indikator kesehatan ibu dan kesejahteraan masyarakat. Angka kematian ibu (AKI) mengacu pada jumlah kematian ibu yang terkait dengan masa kehamilan,persalianan,dan nifas. ${ }^{1}$

Berdasarkan data Survei Demografi dan Kependudukan Indonesia (SDKI) tahun 2012, angka kematian bayi (AKB) di Indonesia dalam periode lima tahun (2007 - 2012) sebesar 32 per 1000 kelahiran hidup dan kematian balita sebesar 40 per 1000 kelahiran hidup. AKB tahun 2012 sebesar 34 per 1000 kelahiran hidup meningkat dibandingkan dengan data tahun 2010 sebesar 26 per 1000 kelahiran hidup, dengan target tahun 2015 sebesar 23 per 1000 kelahiran hidup. 60\% kematian bayi di Indonesia terjadi selama periode neonatal (SDKI, 2012).Sedangkan AKB Provinsi NTB menurut SDKI tahun 2012 yaitu 57 per $1000 \mathrm{KH}^{12}$

Kementerian Kesehatan Republik Indonesia Tahun 2010 - 2014, dalam upaya meningkatkan pembangunan bangsa bidang kesehatan melalui (SDGs). Sustainable Development Goals (SDGs) merupakan hasil kesepakatan 189 kepala negara PBB dengan target mencapai kesejahteraan rakyat dan pembangunan masyarakat pada tahun 2015 . Salah satu agenda untuk pencapaian SDGs pada tahun 2030 adalah menurunkan angka kematian bayi/anak setidaknya 12 per 1000 kelahiran hidup. ${ }^{9,10}$

Survey Demografi Kesehatan Indonesia (SDKI) 2012 menyatakan bahwa Angka Kematian Ibu (AKI) di Indonesia mencapai 359 per 100.000 kelahiran hidup, sebagai angka tertinggi di bandingkan negara ASEAN lainnya seperti Thailand hanya 44 per 100.000 kelahiran hidup, Malaysia 39 per 100.000 kelahiran hidup, dan Singapura 6 per 100.000 kelahiran hidup (BPS, 2012). Tingginya angka kematian ibu ini disebabkan oleh berbagai penyebab yang kompleks, yaitu penyebab langsung dan tidak langsung. Penyebab langsung kematian ibu di Indonesia adalah perdarahan, infeksi, eklamsi, partus lama dan komplikasi abortus, serta penyebab tidak langsung yaitu sosial, budaya, ekonomi, tingkat pendidikan, fasilitas pelayanan kesehatan, dan gender.Hal ini menempatkan upaya penurunan AKI sebagai program prioritas pemerintah. ${ }^{12}$ 
Di Propinsi NTB angka AKI tahun 2012 mencapai 106 per 100.000 kelahiran hidup dan di tahun 2013 mencapai 113 per 100.000 kelahiran hidup (Dinas Kesehatan Provinsi NTB, Tahun 2013). Berdasarkan kecenderungan angka tersebut, akan sulit dicapai target MDG tahun 2015. Penurunan AKI hanya mencapai 52\% dari keadaan tahun 1990 dari target $75 \%$ dan penurunan AKB mencapai $53 \%$ dari target $67 \%$.

Angka kematian ibu masih tinggi, sebenarnya angka kematian tersebut masih bisa dihindari karena sebagian besar bisa terjadi pada saat pertolongan pertama sangat diperlukan, tetapi penyelenggaraan kesehatan tidak sanggup untuk memberikan pelayanan. Kematian dan kesakitan ibu dan perinatal juga berkaitan dengan pertolongan persalian dengan dukun sebanyak $80 \%$ dan berbagai faktor sosial budaya dan faktor

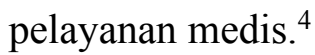

Salah satu upaya untuk menurunkan yaitu dengan Program Perencanaan Persalinan dan Pencegahan Komplikasi (P4K). Pada tahun 2007 menteri kesehatan merencanakan program perencanaan persalinan dan pencegahan komplikasi (P4K) dengan stiker merupakan upaya trobosan dalam upaya percepatan penurunan angka kematian ibu dan bayi baru lahir. Melalui kegiatan peningkatan akses dan kualitas pelayanan, yang sekaligus merupakan kegiatan yang membangun potensi masyarakat, khususnya kepedulian masyarakat untuk persiapan dan tindakan dalam menyelamatkan ibu dan bayi baru lahir. ${ }^{5}$

Program Perencanaan Persalinan Dan Pencegahan Komplikasi (P4K) yang dicanangkan pemerintah bertujuan memantau kehamilan menuju persalinan yang aman dan selamat dan sasarannya adalah seluruh ibu hamil. Indikator P4K adalah dengan pemasangan stiker $\mathrm{P} 4 \mathrm{~K}$ yang terdiri dari penolong persalinan, tempat persalinan, pendamping persalinan, transportasi, dan calon pendonor darah. Karena semua ibu hamil yang telah diberikan stiker dapat terpantau oleh semua komponen masyarakat, suami, keluarga, dan bidan secara tepat dan cepat (Anonim, 2007)

Berdasarkan penelitian Nurani Dewi Dkk 2013, yang berjudul "Gambaran Tingkat Pengetahuan Ibu Hamil Tentang Program Perencanaan Persalinan Dan Pencegahan Komplikasi" menyatakan meskipun tingkat pengetahuan ibu dalam kategori baik tetapi masih ada ibu hamil yang tingkat pengetahuannya kurang.

Berdasarkan Penelitan Indah Retnowati \& Asih Dwi Astuti 2010,Yang Berjudul "Hubungan Penerapan Program Perencanaan Persalinan Dan Pencegahan Komplikasi (P4k) Oleh Ibu Hamil Dengan Upaya Pencegahan Komplikasi Kehamilan"menyatakan Pendidikan yang tinggi tidak menjamin ibu hamil menerapkan P4K. ${ }^{4}$

Berdasarkan data yang didapatkan dari Dikes Lobar Tahun 2017 Puskesmas Gunung Sari memiliki ibu hamil terbanyak di Kabupaten Lombok Barat dengan jumlah 1.372 orang dan ibu hamil yang mengalami komplikasi maternal sebayak 237 orang. Dari $1.372 \mathrm{ibu}$ hamil masih terdapat ibu hamil yang mengalami komplikasi. Berdasarkan fenomena diatas peneliti terdorong untuk mengetahui "Faktor-Faktor yang Berhubungan dengan Pemahaman Ibu Hamil Tentang Stiker P4K" Di Wilayah Kerja Puskesmas Gunungsari. 


\section{Metode}

Desain penelitian merupakan pedoman dan langkah-langkah yang akan diikuti oleh peneliti untuk melakukan penelitiannya. Jenis penelitian yang digunakan dalam penelitian ini adalah Observasi Analitik dengan pendekatan cross sectional. Rancangan cross sectional merupakan rancangan penelitian dengan melakukan pengukuran atau pengamatan pada scat bersamaan/sekali waktu. Populasi dari penelitian ini adalah seluruh ibu hamil yang telah melakukan kunjungan (K1) pada 3 bulan terakhir di Wilayah Kerja Puskesmas Gunung Sari dengan jumlah 95 orang (Profil Puskesmas Gunung Sari, 2018). Sedangkan sampel dalam penelitan ini sebanyak 30 responden.

\section{Hasil dan Pembahasan}

1. Karakteristik Responden

a) Umur

Umur adalah lama waktu hidup atau ada (sejak dilahirkanatau diadakan). Usia aman untuk kehamilan dan persalinan adalah 20-35 tahun. Pada penelitian ini umur dikategorikan dalam 3 kategori yaitu $<20$ tahun, 20-35 tahun, dan $>35$ tahun untuk lebih jelasnya dapat diketahui pada tabel 1.

Tabel 1. Distribusi Frekuensi Responden Berdasarkan Umur Di Wilayah Kerja UPT BLUD Puskesmas Gunungsari Tahun 2018

\begin{tabular}{ccc}
\hline Umur & $\mathbf{n}$ & $\mathbf{\%}$ \\
\hline$<20$ Tahun & 1 & 3,3 \\
$20-35$ Tahun & 26 & 86,7 \\
$>35$ Tahun & 3 & 10,0 \\
\hline Jumlah & 30 & 100,0 \\
\hline
\end{tabular}

Berdasarkan tabel 1 diatas menunjukkan karakteristik responden dari umur ini adalah sebagian besar responden mempunyai umur 20-35 tahun yaitu sebanyak 26 orang $(86,7 \%)$, sebagian kecil mempunyai umur $<20$ tahun sebanyak 1 orang $(3,3 \%)$.

b) Pendidikan

Pendidikan mempengaruhi proses belajar, makin tinggi pendidikan seseorang makin mudah orang tersebut untuk menerima informasi. Pada penelitan ini pendidikan dikategorikan dalam 5 kategori yaitu tidak sekolah, tamat SD, tamat SMP, tamat SMA, dan perguruan tinggi, untuk lebih jelasnya dapat diketahui pada tabel 2.

Tabel 2 Distribusi Frekuensi Responden Berdasarkan Pendidikan di Wilayah Kerja UPT BLUD Puskesmas Gunungsari Tahun 2018

\begin{tabular}{ccc}
\hline Pendidikan & $\mathrm{n}$ & $\%$ \\
\hline Dasar & 11 & 36,7 \\
Menengah & 4 & 13,3 \\
Tinggi & 15 & 50,0 \\
\hline Jumlah & 30 & 100,0 \\
\hline
\end{tabular}


Berdasarkan tabel 2 diatas menunjukkan karakteristik responden dari pendidikan ini adalah sebagian besar responden mempunyai pendidikan tamat SMA yaitu sebanyak 15 orang $(50,0 \%)$, dan sebagian kecil responden mempunyai pendidikan tamat SMP sebanyak 4 orang $(13,3 \%)$.

c) Pekerjaan

Pekerjaan juga merupakan faktor yang dapat mempengaruhi pengetahuan dimana pekerjaan merupakan suatu kegiatan atau aktifitas seseorang untuk memperoleh penghasilan agar kebutuhan dapat terpenuhi. Pada penelitan pekerjaan di kategorikan menjadi tidak bekerja dan bekerja untuk lebih jelasnya dapat diketahui pada tabel 3 .

Tabel 3 Distribusi Frekuensi Responden Berdasarkan Pekerjaan di Wilayah Kerja UPT BLUD Puskesmas Gunungsari Tahun 2018

\begin{tabular}{ccc}
\hline Pekerjaan & n & \% \\
\hline Tidak bekerja & 27 & $90,0 \%$ \\
Bekerja & 3 & $10,0 \%$ \\
\hline Jumlah & 30 & $100,0 \%$
\end{tabular}

Berdasarkan tabel 3 di atas menunjukkan karakteristik responden dari pekerjaan ini adalah sebagian besar responden mempunyai pekerjaan tidak bekerja yaitu sebanyak 27 orang $(90,0 \%)$.

d) Paritas

Paritas adalah jumlah kehamilan yang dilahirkan atau jumlah anak yang dimiliki baik dari hasil perkawinan sekarang atau sebelumnya. Pada penelitian paritas di kategorikan menjadi 3 yaitu primipara, multipara, grande multipara, untuk lebih jelasnya dapat diketahui pada tabel 4 .

Tabel 4 Distribusi Frekuensi Berdasarkan Berdasarkan Paritas di Wilayah Kerja UPT BLUD Puskesmas Gunungsari Tahun 2018.

\begin{tabular}{ccc}
\hline Paritas & $\mathrm{n}$ & $\%$ \\
\hline Primipara & 8 & 26,7 \\
Multipara & 22 & 73,3 \\
\hline Jumlah & 30 & 100,0 \\
\hline
\end{tabular}

Berdasarkan tabel 4 di atas menunjukkan karakteristik responden dari paritas adalah sebagian besar responden multipara yaitu sebanyak 22 responden(73,3\%).

e) Pemahaman

Pemahaman (comprehension) adalah kemampuan seseorang untuk mengerti dan memahami sesuatu setelah sesuatu itu diketahui atau diingat, yang mencakup kemampuan untuk menangkap makna dari arti dan bahan yang telah dipelajari, yang dinyatakan dengan menguraikan isi pokok dari suatu bacaan, atau mengubah data yang disajikan dalam bentuk tertentu ke bentuk yang lain. Pada penelitian pemahaman di kategorikan menjadi 2 yaitu paham dan tidak paham, untuk lebih jelasnya dapat diketahui pada tabel 5 . 
Tabel 5 Distribusi Frekuensi Berdasarkan Pemahaman diWilayah Kerja UPT BLUD Puskesmas Gunungsari Tahun 2018.

\begin{tabular}{llc}
\hline \multicolumn{1}{c}{ Pemahaman } & $\mathrm{n}$ & $\%$ \\
\hline Tidak paham & 12 & 40,0 \\
Paham & 18 & 60,0 \\
\hline Jumlah & 30 & 100,0
\end{tabular}

Berdasarkan tabel 5 di atas menunjukkan karakteristik responden dari pemahaman adalah sebagian besar responden paham yaitu sebanyak 18 orang $(60,0 \%)$.

\section{Hubungan karakteristik responden dengan pemahaman ibu hamil tentang stiker P4K.}

Berikut dipaparkan hasil penelitian yang meliputi,hubungan umur,pendidikan, pekerjaan,dan paritas, dengan pemahaman ibu hamil tentang stiker P4K di Wilayah Kerja UPT BLUD Puskesmas Gunungsari Tahun 2018.

1) Umur

Tabel 6. Hubungan Umur dengan Pemahaman Ibu Hamil Tentang Stiker P4K di Wilayah Kerja UPT BLUD Puskesmas Gunungsari tahun 2018.

\begin{tabular}{|c|c|c|c|c|c|c|c|}
\hline \multirow{3}{*}{$\begin{array}{l}\text { Hubungan } \\
\text { Umur }\end{array}$} & \multicolumn{4}{|c|}{ Pemahaman } & \multicolumn{2}{|c|}{ Total } & \multirow[t]{3}{*}{ Nilai $p$} \\
\hline & \multicolumn{2}{|c|}{ Paham } & \multicolumn{2}{|c|}{$\begin{array}{c}\text { Tidak } \\
\text { Paham }\end{array}$} & $\mathrm{n}$ & $\%$ & \\
\hline & $\mathrm{n}$ & $\%$ & $\mathrm{n}$ & $\%$ & & & \\
\hline$<20$ dan $20-35$ & 17 & 63 & 10 & 37 & 27 & 100 & \\
\hline$>35$ & 1 & 33 & 2 & 67 & 3 & 100 & 0,548 \\
\hline Jumlah & 18 & 60 & 12 & 40 & 30 & 100 & \\
\hline
\end{tabular}

Tabel 6 menunjukkan berdasarkan hasil analisa hubungan antara umur dengan pemahaman ibu hamil tentang stiker P4K dari 30 responden didapatkan bahwa responden dengan umur $<20$ dan 20-35 tahun yang paham berjumlah 17 orang $(63 \%)$ dan yang tidak paham 10 orang $(37 \%)$, sedangkan responden yang memiliki umur $>35$ tahun yang paham terhadap stiker P4K sebanyak 1 orang (33\%) sedangkan responden yang tidak paham sebanyak 2 orang (67\%).Hasil uji statistik dengan menggunakan Chi-squere menggambarkan tidak ada hubungan yang bermakna antara umur dengan pemahaman ibu hamil tentang stiker P4K di Wilayah Kerja UPT BLUD Puskesmas Gunungsari. 
2) Pendidikan

Tabel 7 Hubungan Pendidikan dengan Pemahaman Ibu HamilTentang Stiker P4K di Wilayah Kerja UPT BLUD Puskesmas Gunungsari tahun 2018 .

\begin{tabular}{|l|c|c|c|c|c|c|c|}
\hline \multirow{3}{*}{$\begin{array}{c}\text { Hubungan } \\
\text { Pendidikan }\end{array}$} & \multicolumn{4}{|c|}{ Pemahaman } & \multicolumn{2}{c|}{ Total } & Nilai p \\
\cline { 2 - 8 } & \multicolumn{2}{|c|}{ Paham } & \multicolumn{2}{c|}{$\begin{array}{c}\text { Tidak } \\
\text { Paham }\end{array}$} & $\mathrm{n}$ & $\%$ & \\
\cline { 2 - 9 } & $\mathrm{n}$ & $\%$ & $\mathrm{~N}$ & $\%$ & & & \\
\hline $\begin{array}{l}\text { Dasar dan } \\
\text { menengah }\end{array}$ & 4 & 27 & 11 & 73 & 15 & 100 & \multirow{2}{*}{0,001} \\
\hline Tinggi & 14 & 93 & 1 & 7 & 15 & 100 & \\
\hline Jumlah & 18 & 60 & 12 & 40 & 30 & 100 & \\
\hline
\end{tabular}

Tabel 7 menunjukkan berdasarkan hasil analisa hubungan antara pendidikan dengan pemahaman dari 30 responden didapatkan bahwa responden dengan pendidikan dasar dan menengah yang paham tehadap stiker P4K sebanyak 4 orang $(27 \%)$, sedangkan responden yang tidak paham sebanyak 11 orang (73\%), responden dengan pendidikan tinggi yang paham terhadap stiker P4K sebanyak 14 orang (93\%), sedangkan yang tidak paham sebanyak 1 orang (7\%). Hasil uji statistik dengan menggunakan Chi-squere menggambarkan ada hubungan yang bermakna antara pendidikan dengan pemahaman ibu hamil tentang stiker P4K di Wilayah Kerja UPT BLUD Puskesmas Gunungsari.

3) Pekerjaan

Tabel 8 Hubungan pekerjaan dengan pemahaman ibu hamil tentang Stiker P4K di Wilayah Kerja UPT BLUD Puskesmas Gunungsari tahun 2018.

\begin{tabular}{|c|c|c|c|c|c|c|c|}
\hline \multirow{3}{*}{$\begin{array}{l}\text { Hubungan } \\
\text { Pekerjaan }\end{array}$} & \multicolumn{4}{|c|}{ Pemahaman } & \multicolumn{2}{|c|}{ Total } & \multirow[t]{3}{*}{ Nilai $p$} \\
\hline & \multicolumn{2}{|c|}{ Paham } & \multicolumn{2}{|c|}{ Tidak Paham } & \multirow[t]{2}{*}{$\mathrm{n}$} & \multirow[t]{2}{*}{$\%$} & \\
\hline & $\mathrm{n}$ & $\%$ & $\mathrm{n}$ & $\%$ & & & \\
\hline Bekerja & 0 & 0 & 3 & 100 & 3 & 100 & \\
\hline $\begin{array}{l}\text { Tidak } \\
\text { Bekerja }\end{array}$ & 18 & 67 & 9 & 33 & 27 & 100 & 0,054 \\
\hline Jumlah & 18 & 60 & 12 & 40 & 30 & 100 & \\
\hline
\end{tabular}

Tabel 8 menunjukkan berdasarkan hasil analisa hubungan antara pekerjaan dengan pemahaman dari 30 responden didapatkan bahwa responden yang bekerja yang paham terhadap stiker P4K $0(0 \%)$, sedangkan responden yang tidak paham sebanyak 3 orang $(100 \%)$ dan responden tidak bekerja yang paham terhadap stiker P4K sebanyak 18 orang (67\%), sedangkan responden yang tidak paham sebanyak 9 orang (33\%). Hasil uji statistik dengan menggunakan Chi-squere menggambarkan ada hubungan yang bermakna antara umur dengan pemahaman ibu hamil tentang stiker P4K di Wilayah Kerja UPT BLUD Puskesmas Gunungsari. 
4) Paritas

Tabel 9 Hubungan Paritas dengan pemahaman ibu hamil tentang stiker P4K di Wilayah Kerja UPT BLUD Puskesmas Gunungsari tahun 2018.

\begin{tabular}{lccccccc}
\hline \multirow{2}{*}{$\begin{array}{c}\text { Hubungan } \\
\text { Paritas }\end{array}$} & \multicolumn{4}{c}{ Pemahaman } & \multicolumn{2}{c}{ Total } & Nilai $\mathrm{p}$ \\
\cline { 2 - 7 } & \multicolumn{2}{c}{ Paham } & \multicolumn{1}{c}{$\begin{array}{c}\text { Tidak } \\
\text { Paham }\end{array}$} & $\mathrm{n}$ & $\%$ & \\
\cline { 2 - 7 } & $\mathrm{n}$ & $\%$ & $\mathrm{n}$ & $\%$ & & \\
\hline Primipara & 8 & 100 & 0 & 0 & 8 & 100 & \\
\hline Multipara & 10 & 45 & 12 & 55 & 22 & 100 & \multirow{2}{*}{0,004} \\
\hline Jumlah & 18 & 60 & 12 & 40 & 30 & 100 & \\
\hline
\end{tabular}

Tabel 49 menunjukkan berdasarkan hasil analisa hubungan antara paritas dengan pemahaman dari 30 responden didapatkan bahwa responden dengan primipara yang paham terhadap stiker P4K sebanyak 8 orang (100\%), sedangkan yang tidak paham sebanyak $0(0 \%)$, responden dengan multipara yang paham terhadap stiker $\mathrm{P} 4 \mathrm{~K}$ sebayak 10 orang (45\%),sedangkan responden yang tidak paham sebanyak 12 orang (55\%). Hasil uji statistik dengan menggunakan Chi-squere menggambarkan ada hubungan yang bermakna antara umur dengan pemahaman ibu hamil tentang stiker P4K di Wilayah Kerja UPT BLUD Puskesmas Gunungsari.

\section{A. Karakteristik Responden}

1. Usia

Berdasarkan hasil penelitian ini,sebagian besar ibu hamil yang menjadi responden pada penelitian pemahaman berumur 20-35 tahun sebanyak 26 orang $(86,7 \%)$. Umur yang sudah matang akan mempengaruhi pola pikir seorang ibu, sehingga ibu akan patuh dalam perawatan kehamilan. Ibu hamil yang berusia 20 hingga 30 tahun telah masuk dalam rentang usia dewasa awal, dimana ibu mulai mengalami proses kematangan emosional dan mampu menerima informasi dengan baik serta mengambil keputusan yang tepat mengenai perilaku kesehatan selama kehamilan, sehingga ibu hamil akan semakin sadar untuk mencariinformasi tentang stiker P4K. ${ }^{13}$

2. Pendidikan

Keseluruhan ibu hamil yang menjadi responden dalam penelitian tentang pemahaman stiker P4K memiliki tingkat pendidikan SMA sebanyak 15 orang $(50,0 \%)$, sehingga akan mempengaruhi terbentuknya pengetahuan, sikap maupun perilaku seseorang menjadi lebih baik. Semakin tinggi tingkat pendidikan ibu hamil maka semakin baik pula tingkat kesadaran mengenai pentingnya kesehatan sehingga perilaku kesehatan juga akan semakin membaik. Latar belakang pendidikan ibu hamil juga sangat mempengaruhi pemahaman ibu hamil dalam mencari dan mendapatkan informasi tentang stiker P4K. ${ }^{8}$ 
Menurut Soekidjo (2003) pendidikan adalah upaya untuk memberikan pengetahuan sehingga terjadi perubahan perilaku positif yang meningkat, pendidikan akan memberikan pengetahuan sehingga terjadi perubahan perilaku dan tingkat pengetahuan lebih meningkat.

3. Pekerjaan

Untuk pekerjaan seluruh ibu hamil yang menjadi responden dalam penelitian pemahaman stiker $\mathrm{P} 4 \mathrm{~K}$ keseluruhan ibu hamil tidak bekerja atau sebagai ibu rumah tangga sebanyak 27 orang $(90,0 \%)$. Hal ini membuktikan bahwa dapat diketahui bahwa seorang ibu rumah tangga memungkinkan mereka mempunyai waktu untuk mencari informasi kesehatan terutama tentang stiker $\mathrm{P} 4 \mathrm{~K}$, disebabkan karena ibu rumah tangga lebih banyak menghabiskan waktunya di rumah dan lebih banyak informasi yang didapat baik dari ibu sendiri,tenaga kesehatan,maupun dari teman dan keluarga. Tidak selamanya pekerjaan di luar rumah memiliki pengetahuan lebih baik dan luas tentang Stiker P4K. Oleh karena itu rendahnya pekerjaan seseorang tidak mempengaruhi dalam mencari dan memperluas wawasan dan pengetahuan. ${ }^{17}$

4. Paritas

Untuk jumlah paritas hasil penelitian ibu hamil didapatkan primipara sebanyak 8 orang paham $(100 \%)$ dan multipara yang paham terhadap stiker P4K sebanyak 10 orang (45\%) sedangkan yang tidak paham sebanyak 12 orang (55\%). Jika dilihat dari segi pengalaman dimana pengalaman juga mepengaruhi bagaimana ibu menghadapi persalinannya sehingga ibu sebelumnya memiliki gambaran apa yang akan dilakukan jika persalinan terjadi lagi. ${ }^{5}$

Berbeda dengan ibu primipara yang belum memiliki pengalaman sehingga tidak ada gambaran tentang bagaimana cara mengahadapi proses persalinan. $^{11}$

\section{B. Pemahaman ibu hamil tentang stiker P4K di wilayah kerja Puskesmas Gunung Sari Tahun 2018}

Pemahaman merupakan salah satu tingkatan dari pengetahuan yang dimana tingkatan pengetahuan tersebut diawali dengan tahu. Tahu ialah mengingat kembali satu materi yang telah dipelajari sebelumnya. Kemudian setelah tahu seseorang mampu memahami, memahami merupakan suatu kemampuan menjelaskan, menyebutkan contoh, menyimpulkan, meramalkan, dan sebagainya terhadap suatu obyek yang dipelajari. Dalam hal ini tahu merupakan bagian dari proses memehami, sehingga faktor-faktor yang berhubungan dengan pengetahuan juga dapat berhubungan dengan pemahaman seseorang. ${ }^{4}$

Berdasarkan hasil penelitian yang dilakukan diketahui bahwa ibu hamil yang paham terhadap stiker P4K sebanyak 18 orang $(60,0 \%)$ dan responden yang tidak paham sebanyak 12 orang $(40,0 \%)$. 


\section{Hubungan karakteristik responden dengan pemahaman ibu hamil tentang stiker P4K di wilayah kerja UPT BLUD Puskesmas Gunungsari Tahun 2018}

Berdasarkan hasil penelitian pada karakteristik responden yaitu umur, pendidikan,pekerjaan, dan paritas didapatkan hasil uji bahwa tidak terdapat hubungan antara umur dengan pemahaman ibu hamil tentang stiker P4K ( P Value $=0,548$ ). Sedangkan pendidikan ( PValue $=0,001)$, pekerjaan ( $\mathrm{P}$ Value $=0,054$ ), paritas ( $\mathrm{P}$ Value $=0,004$ ) yaitu artinya terdapat hubungan yang signifikan.

\section{Kesimpulan}

Terdapat hubungan yang signifikan antara faktor pendidikan, pekerjaan, paritas dengan pemahaman ibu hamil tentang stiker P4K. Sedangkan faktor umur tidak berhubungan dengan pemahaman ibu hamil tentang stiker P4K.

\section{Daftar Pustaka}

1. Anonim. 2008. Menkes Canangkan Stiker Perencanaan Persalinan dan Pencegahan Komplikasi.

2. Departemen Kesehatan Republik Indonesia. 2009. Pedoman Program Perencanaan Dan Pencegahan Komplikasi Dengan Stiker. Depkes RI : Jakarta.

3. Destria, Dora.2010. Faktor-Faktor Yang Berhubungan Dengan Tingkat Pemahaman Ibu Hamil Terhadap Pesan Antenatal Care Yang Terdapat Didalam Buku Kia. Artikel Ilmiah Fakultas Kedokteran Universitas Diponegoro.

4. Dewi, Nurani Dkk. 2013. Gambaran Tingkat Pengetahuan Ibu Hamil Tentang Program Perencanaan Persalinan Dan Pencegahan Komplikasi. KTI D-III Kebidanan Politeknik Harapan Bersama

5. Dewi, Wila Susanti.2012. Pengaruh Penyuluhan Kesehatan Program Perencanaan Persalinan dan Pencegahan Komplikasi (P4K) Terhadap Pemilihan Penolong Persalinan Oleh Ibu Hamil. Jurnal Kebidanan Universitas Indonesia.RI.

6. Dinas Kesehatan Republik Indonesia. 2016. Data dan Informasi Profil Kesehatan Indonesia 2016. Dikes RI : Jakarta.

7. Dinas Kesehatan Lombok Barat. 2016. Laporan PWS KIA 2016. Dikes Lobar : Lombok Barat

8. Dinas Kesehatan Republik Indonesia. 2009. Pedoman Praktis Program Perencanaan dan Pencegahan Komplikasi (P4K) dengan Stiker. Jakarta: Departemen Kesehatan.

9. Dinas Kesehatan Nusa Tenggara Barat. 2016. Profil Kesehatan NTB 2016. Dikes Provinsi NTB : Mataram.

10. Dinas Kesehatan Nusa Tenggara Barat. 2015. Profil Kesehatan NTB 2015. Dikes Provinsi NTB : Mataram.

11. Lestari, Sri Nur. 2015. Tingkat Pengetahuan Ibu Hamil Tentang Program Perencanaan Persalinan Dan Pencegahan Komplikasi Di RB AN-NUUR, Surakarta 
12. Notoadmodjo, Soekidjo. 2010. Metode Penelitian Kesehatan. Rineka Cipta: Jakarta

13. Notoatmodjo, S. 2011. Kesehatan Masyarakat. Jakarta: Rineka Cipta

14. Notoatmodjo S.2007. Promosi Kesehatan dan Ilmu Perilaku. Rineka Cipta;Jakarta

15. Rani, Masia Tika. 2017. Gambaran Pengetahuan Ibu Hamil Dalam Pelaksanaan Program Perencanaan Persalinan Dan Pencegahan

16. Komplikasi Di Puskesmas Jetis 1 Bantul. KTI Stikes Jenderal Ahmad Yani, Yogyakarta.

17. Retnowati, Indah \& Asih Dwi Astuti.2010. Hubungan Penerapan Program Perencanaan Persalinan Dan Pencegahan Komplikasi OlehIbu Hamil Dengan Upaya Pencegahan Komplikasi Kehamilan. Akademi Kebidanan Estu Utomo Boyolali

18. SDKI. (2012). Survei demografi dan kesehatan Indonesia. Jakarta 